\title{
Harvesting of southern Piedmont's orchards pruning residues: evaluations of biomass production and harvesting losses
}

\author{
M. Grella, M. Manzone, F. Gioelli, P. Balsari \\ Department of Agricultural, Forest and Food Sciences, DISAFA, University of Torino, Italy
}

\begin{abstract}
In recent years, there has been an increasing interest in respect to all farming residues, including orchard pruning residues. The masses and dimensional characteristics of branches pruned, depend on several factors such as fruit variety, active strength plant, training systems, intensity and periodicity pruning. Many studies were done to fix this type of biomass availability, however they're not up-to-date, and usually they are lacking of accurate surveys. A detailed knowledge of current pruning biomass availability, both qualitative and quantitative, is also necessary for the evaluation of the economic sustainability of their energetic exploitation. In this context, in order to provide an assessment of the real chain potential of energy renewable production, from Cuneo territory pruning residues, a research was conducted on two different orchards species Actinidia (Kiwi tree) and Malus (Apple tree) pruned in two different ways: "traditional system" and "taille longue system". For each species, pruning residues amount were quantified together with their diameter. The surveys were performed at least on four half trees placed on the same row spacing with three randomized replications in the crop. The amount of pruning residues were determined by a dynamometer (precision $0.02 \mathrm{~N}$ ) whereas the diameter of individual cut-off branches has been detected at the base of the same using a twentieths calliper. Subsequently were performed pruning residues windrowing by rotating rake and the harvest of the same by fixed chamber round baler suitably modified. At the end of these operations have been determined harvesting losses with the same methodology used for the initial quantification of residues. The first result shows that with the "traditional pruning system" the biomass average
\end{abstract}

Correspondence: Grella Marco, DISAFA, University of Torino, via Leonardo da Vinci 44, 10095 Grugliasco (T0), Italy.

Tel. +39.011.6708610 - Fax: +39.011 .6708591 -

E-mail: marco.grella@unito.it

Keywords: biomass, harvest, losses, orchard, pruning.

Contribution: M. Grella, M. Manzone, data collecting and analyzing; M. Grella, manuscript writing and references search; F. Gioelli, P. Balsari, manuscript reviewing; P. Balsari research planning.

Conflict of interest: the authors declare no potential conflict of interest.

(C) Copyright M. Grella et al., 2013

Licensee PAGEPress, Italy

Journal of Agricultural Engineering 2013; XLIV(s2):e108

doi:10.4081/jae.2013.s2.e108

This article is distributed under the terms of the Creative Commons Attribution Noncommercial License (by-nc 3.0) which permits any noncommercial use, distribution, and reproduction in any medium, provided the original author(s) and source are credited. availability is of $2.5 \mathrm{t} \mathrm{DM} \mathrm{ha}{ }^{-1}$ and $3.0 \mathrm{t} \mathrm{DM} \mathrm{ha-1}$, respectively for kiwi tree and apple tree. For the latter, the average values are significantly lower $0.5 \mathrm{t} \mathrm{DM} \mathrm{ha}{ }^{-1}$ with "taille longue" pruning system. The harvesting losses have been nearly $19 \%$ in kiwi tree and 16\% for apple tree (from $95 \%$ to $11 \%$ according to the variety). In both crops the variation of harvester losses are due mainly to the size and conformation (straight) of pruned branches.

\section{Introduction}

Within the national energy scenario, the production of energy from alternative sources is an issue of basic importance and interest, especially in view of two opposing factors: the need to comply the aims of greenhouse gas emissions under the Directive 2009/29 EC so-called "climate-energy package 20-20-20" (reduction of greenhouse gas emissions by $20 \%$, increasing to $20 \%$ the share of energy produced from renewable sources and achieve a $20 \%$ energy savings, all by 2020 ), and the growing energy needs that require an organic saving policy. In this regard, the commitments Italy have to respect impose a serious and urgent assessment for using renewable sources for energy. In this context is located the use of biomass energy, as defined by Article 2 of Legislative Decree 29 December 2003, number 387 (text updated according to the changes introduced by Law number 99/2009) as "the biodegradable fraction of products, waste and residues from agriculture (including vegetal and animal substances), forestry and related industries, as well as the biodegradable fraction of industrial and municipal waste".

Agriculture is one of the main sectors for supplying renewable fuels. In Italy this sector has particular importance considering that, there are no significant high productive crops (Short Rotation Forestry) specifically dedicated to this purpose (Biomasse Italia S.p.A., 2008; Manzone M., 2006). The main problem of the biomass energy enhancement is in fact related to supply's difficulties: the agricultural sector is able to provide different types of biomass, rising from the herbaceous energy crops to woody, from dedicated to residual productions. In agriculture the potential of residual woody biomass is mostly represented by the pruning of orchards, olive tree and vines (ENAMA, 2011). These biomasses are cut and generally laid down on the soil between the rows or harvested and burned on the sideline. They represent a serious problem for the development of parasites and uncontrolled fires (Vita in Campagna, 2012). Furthermore their management represents a huge additional cost for farmers (Cotana et al., 2008). Nevertheless, the use of such wastes for energy production could solve the problem of their disposal, reduce the management costs for the farmer and, at the same time, increase the economic revenue of the farm. Several studies (CNR, 2012; ENAMA, 2011; ENEA, 2010; ISTAT, 2010; ITABIA, 2005) were conducted on the technical characteristics and the availability of biomass and biofuels. Nevertheless the amount of agricultural residues is generally determined by multiplying the cultivated surface with coefficients describing the residues 
productivity (CESTAAT, 1990). The information given are consequently often too general and do not allow to be transfer to a specific site.

These studies providing a comprehensive overview, but the heterogeneity of orchards make necessary focused surveys for a new knowledge of framework. Only on the basis of these new knowledge, we will be able to real assess the area vocation for that specific bioenergy supply chain.

The project "Energy from the orchard: an example of supply chain for the production of renewable energy from orchards pruning" (FRUITGAS), funded by the European Union within the Measure 124 of the Rural Development Programme (F.E.A.S.R. 2007/2013 - CHALLENGES "HEALTH CHECK") is carried out nearby two representative orchard farms of Piedmont region, located in the Cuneo (CN) Province.

The project is divided into different activities that can be summarized in the collection, storage and energy use of pruning residues of different fruit tree species.

The project is in its first year of development and to date has been performed pruning, windrowing the harvest and transport to the farm of biomass while are currently an ongoing storage and drying phases.

The work focuses on the quantitative and dimensional characterization of the orchards pruning in order to: understand this influence on the harvesting losses in relation to the machine used. To optimize the harvesting machine collection system of the pruning in function of dimension of the same.

\section{Materials and methods}

Two species of fruit tree in terms of woody biomass suitable for energy use have been considered: Actinidia spp. (Kiwi tree) and Malus spp. (apple tree). These two species are at present the most representative ones of the Cuneo area, covering a surface of 4454.61ha and 3482.53ha respectively (ISTAT, 2010).

For the apple tree two different pruning techniques were compared (Table 1), "traditional" and "taille longue" (pruning method which provides for the free growth of the branches, which are not shortened, and the reduction of bending interventions)(Musacchi et al., 2011; Diemoz et al., 2003), and four different variety: Gala, Scarlett, Ambrosia and Golden all spindle trained. The first three varieties have the same rootstock (M9), and the fourth have M26 rootstock. Furthermore, in order to verify a possible effect of the plant age in the production of biomass, orchards of different age (Table 1) were compared. For the Kiwi tree only the crops age (Table 1) was considered due to the fact that Hayward is currently the only cultivated variety always managed with the same pruning system called "traditional".

For each species, variety and planting year the mass of the pruning residues through direct surveys within the crops was determined. The size classification of each branch was determined as well.

The surveys were performed on portions of the row spacing at least 4 meters long, at a distance greater than 10 meters from the sideline and on rows not placed on the edge of plot. Adopting these parameters, the number of plants insisting on each survey area was different according to the trees spacing: 4 half kiwi tree and 10 to 20 half apple tree. All measurements were performed with three replicates randomly distributed inside the experimental plot.

The quantification of the cut material was made by the weighing of the branches divided into diameter classes of regular width of 5 millimeters. The determination of the weight was achieved by using a digital dynamometer (Sicutool SCU 4488B) with a precision of 0.02 Newton (N), while for the measurement of the diameters was used a mechanical twentieths Vernier callipers (Valex_1800308).

The biomass production was estimated by analytical calculation between the material weighed in the individual areas of survey and the total crop area. The latter parameter was expressed in dry matter for unit area ( $\left.\mathrm{t} \mathrm{DM} \mathrm{ha}{ }^{-1}\right)$.

The dry matter content of the pruning residues was measured as the difference in weight of fresh material and after drying in a forced ventilation oven (Controls D1396-10) for about 24 hours at a temperature of $103^{\circ} \mathrm{C}$.

In order to quantify the biomass actually harvestable, the material has been appropriately ordered in swaths through a rake (GIRORAMI new $8 \mathrm{BC}$ ) and subsequently harvested by a fixed-chamber roundbaler for forages (LERDA 135). The roundbaler was previously modified so that it was able to realize conglomerates of biomass of considerable weight (about 0,5 tons of raw materials with 150 bar $\left(1 \mathrm{bar}=10^{5} \mathrm{~Pa}\right)$ of pressure in the compression chamber) and to reduce the cost of transportation in a perspective of a future large-scale use of this biofuel.

The harvest losses are detected with the same methodology described above for the quantification of total biomass production (survey area was different according to the trees spacing, with three replicates randomly distributed inside the experimental plot).

\section{Results and discussion}

\section{Analysis of diameter classes}

The collected data (Figure 1) showed that the kiwi tree has branches of larger diameter than those of the apple tree. A different distribution inside diameter classes is obtained also considering the different apple tree pruning system, in the taille longue over $90 \%$ of the diameters fall in the first and second classes, while with the traditional pruning system the majority of the branches (95\%) is divided into the first three classes.

In fact, the traditional pruning system reflected in a greater vigor of

Table 1: Technical characteristics of the experimental orchards under investigation.

\begin{tabular}{|c|c|c|c|c|c|}
\hline Species & Variety & Plant year & Rootstock & Coltivation technique & Pruning technique \\
\hline Kiwi & Hayward & 2004 & / & Arbor & traditional \\
\hline Kiwi & Hayward & 1988 & I & Arbor & traditional \\
\hline Melo & Scarlett & 1999 & M9 PAJAN2 & Spindle & taille longue \\
\hline Melo & Gala & 1999 & M9 & Spindle & taille longue \\
\hline Melo & Ambrosia & 2007 & M9 & Spindle & taille longue \\
\hline Melo & Gala & 2003 & M9 & Spindle & traditional \\
\hline Melo & Golden & 1990 & M26 & Spindle & traditional \\
\hline
\end{tabular}


the plant, promoting the production of branches of greater diameter, while the taille longue system produce a lower woody biomass due to a lower number of cut-off branches for smaller diameter.

\section{Analysis of the amount of biomass produced.}

Similarly to what has been observed in the diametric analysis of the cut branches, the amount of produced biomass (Figure 2) reflects the adopted pruning system. Regardless to the considered apple tree varieties, the taille longue pruning system produces an average of $0.46 \mathrm{t}$ $\mathrm{DM} \mathrm{ha}^{-1}$ while the traditional pruning system $3.04 \mathrm{t} \mathrm{DM} \mathrm{ha}^{-1}$.

Within the apple tree pruned by the taille longue techniques the types that contributed to a lesser extent to the production of biomass (0.10 t DM ha $\left.{ }^{-1}\right)$ was the var. ambrosia ( $-87.5 \%$ compared to var. gala), whereas the greater production was achieved with the var. gala $(0.83 \mathrm{t}$ $\left.\mathrm{DM} \mathrm{ha}^{-1}\right)$. Intermediate values were obtained with the var. scarlett 0.44 t DM ha ${ }^{-1}$ (-46.6\% compared to var. gala). With the traditional pruning system, apple tree produced an average of about $3 \mathrm{t} \mathrm{DM} \mathrm{ha}^{-1}$ which is approximately 4.5 times higher than the taille longue pruning system. The greatest amount of biomass is obtained with the apple tree var. golden with $3.87 \mathrm{t} \mathrm{DM} \mathrm{ha}{ }^{-1}$ while the smaller one with the var. gala with 2.21 t DM ha ${ }^{-1}$ (-43.0\% compared to var. golden).

For the kiwi tree, the production of biomass on average amounted to $2.51 \mathrm{t} \mathrm{DM} \mathrm{ha}{ }^{-1}$, a value very close to that found for the apple tree pruned with the traditional system. The kiwi plants of 2004 produced $3.10 \mathrm{t}$ DM $\mathrm{ha}^{-1}$ of biomass corresponding to $+37.9 \%$ yield when compared to that of the plants from $1988\left(1.93 \mathrm{t} \mathrm{DM} \mathrm{ha}{ }^{-1}\right)$.

\section{Analysis of losses at harvest}

As shown in Figure 3 with the taille longue pruning system on average the $47 \%$ of the pruning residues were lost at harvest. Losses recorded with the traditional pruning system were considerably lower (on average of $11 \%$ of the residues). However in var. ambrosia the losses are equal to $95 \%$, significantly higher than the losses average of taille longue pruning system. This trend is due to the different conformation of the pruned branches that in the taille longue pruning system are characterized by a small diameter (no more than $15 \mathrm{~mm}$ ), high straightness and limited length (in the ambrosia type the length of the branches never exceeds $300 \mathrm{~mm}$ ). The traditional pruning system showed losses very similar regardless of the considered varieties of apple tree.

In kiwi tree, regardless to the trees age the values of the harvest losses are around $19 \%$ of the available biomass. In this case, the harvest losses are mainly due to the straightness of the branches that barely adapt to harvest mechanical system of the round balers on the market.

Analyzing data of lost biomass expressed as the amount of dry matter ( $\mathrm{t} \mathrm{DM} \mathrm{ha}{ }^{-1}$ ) the trend is reversed than the losses percentage. The lesser quantity losses ranging from 0.10 to $0.34 \mathrm{t} \mathrm{DM} \mathrm{ha}^{-1}$ for the apple tree pruned with taille longue system and intermediate values from 0.29 to $0.38 \mathrm{t} \mathrm{DM} \mathrm{ha}^{-1}$ for the apple tree pruned with the traditional system. The kiwi tree recorded the greatest quantity losses ranging from 0,38 to $0.58 \mathrm{t} \mathrm{DM} \mathrm{ha}^{-1}$.

\section{Conclusions}

The processed data show both the kiwi tree, although when affected by bacterial canker (Pseudomonas syringae pv actinidiae) which limits their vigor (Balestra et al., 2009; Renzi et al., 2012), and the apple tree can guarantee a good production of biomass $\left(2.5-3.0 \mathrm{t} \mathrm{DM} \mathrm{ha}{ }^{-1}\right)$. Nevertheless the harvest of such potential biofuel is extremely difficult and determines heavy biomass losses (from 11 to $47 \%$ of the pruning residues depending on the species, variety and pruning technique).

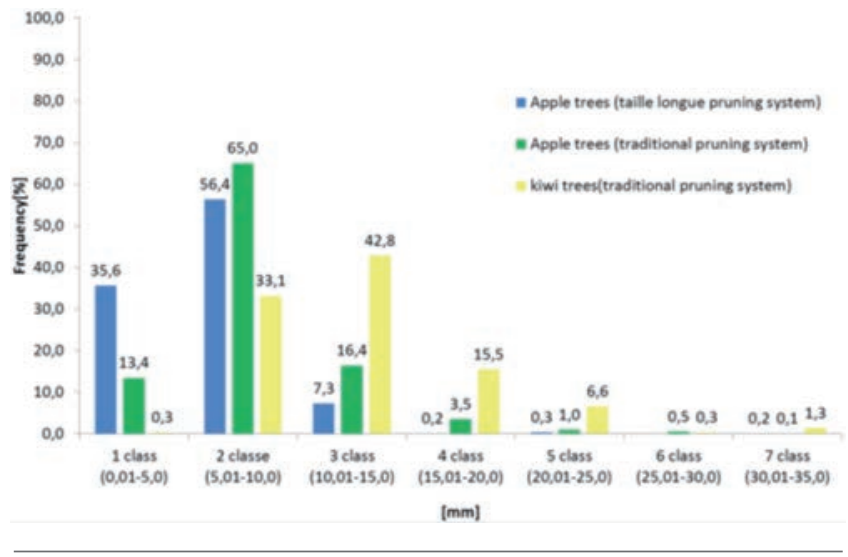

Figure 1. Frequency of pruning branches for diameter class as a function of different pruning systems.

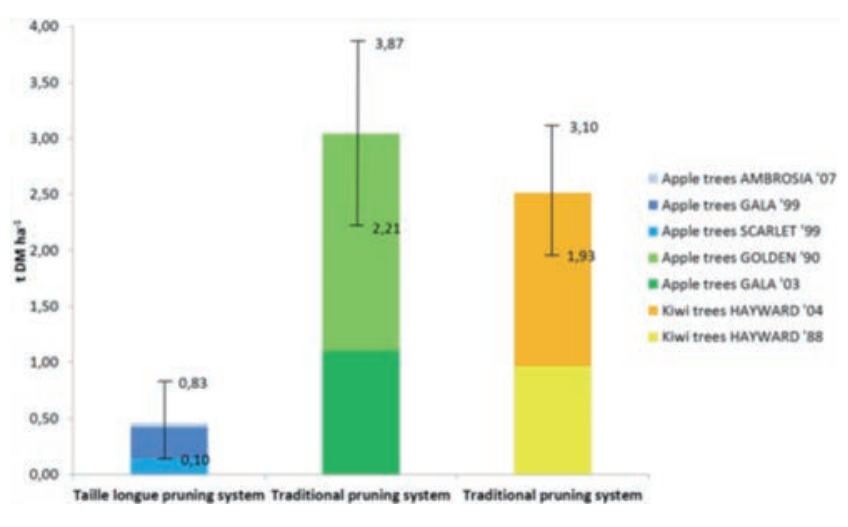

Figure 2. Average pruning residues yield as a function of different pruning system; different colors show how in percentage each variety contributes to the average production.

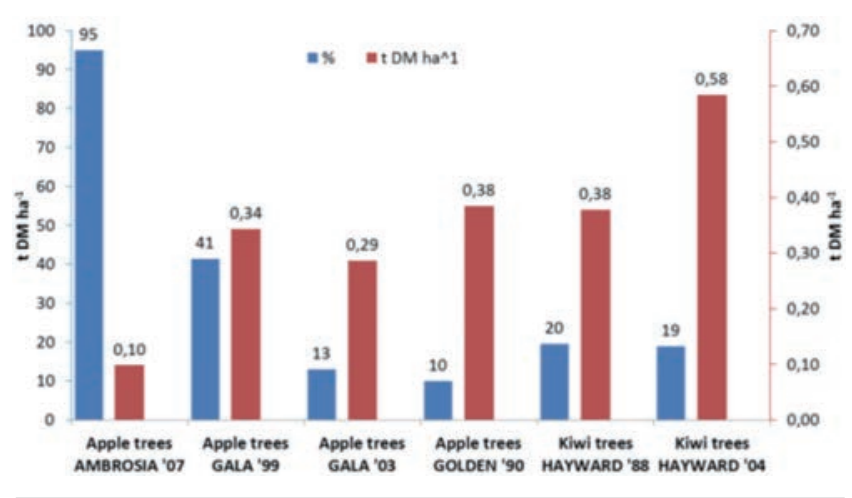

Figure 3. Harvest losses expressed as dry matter [t/ha] and as percentage rates of total biomass production; the data are reported for each species and type. 
However, the experiment highlighted how the pruning system adopted for the apple tree (traditional or taille longue) can have a substantial effect on the biomass production,on the physical characteristics (size pruning branches) and on the harvest losses of the produced woody biomass.

Although at present most of the plants are still grown with the traditional pruning system, the projections into the future show a clear transition to the new pruning system taille longue, because it ensures better quality fruits (Diemoz et al., 2003) with a lower production of prunings residues $(-80 \%)$ that for farms is cost management.

Moreover, it must be pointed out, the new orchards unlike the older ones, having a productive life significantly reduced (max 15 years) inevitably produce a lower amount pruning residues (Bayer Crop Science S.r.l., 2008).

Therefore in the analysis of a possible supply chain aimed at the use of pruning residues as biofuel, we must consider the farming technical evolution (adoption of the new pruning system taille loungue against the traditional pruning system) that underlines a consistent reduction of orchard pruning biomass available. Instead of kiwi tree we must consider the possible removal that potentially could affect all the plants affected by bacterial cancker (no kiwi trees immune to bacterial canker).

In this regard it should be noted that the optimization of the harvesting machine must necessarily be targeted to the harvest of branches characterized by small diameters $(\max 15 \mathrm{~mm})$ and a high straightness that can't be harvested by the traditional pick-ups fitted to the usual fodder roundbalers.

\section{References}

Balestra G. M., Mazzaglia A., Quattrucci A., Renzi M., Rossetti A. 2009. Current status of bacterial canker spread on kiwifruit in italy. Australasian Plant Disease Notes. 4(1):34-36
Bayer Crop Science S.r.l. 2008. Il melo. Script marchio editoriale di ART S.p.A., Bologna, Italy.

Biomasse Italia S.p.A., 2008. La filiera da arboricoltura da legno a ciclo breve (S.R.F.)per Biomasse Italia S.p.A. Available from: http://www.biomasseitalia.it/Download/SRF_Presentazione.pdf. Accessed: May 2013

Centro Studi sull'Agricoltura, l'Ambiente e il Territorio (CESTAAT), 1990. Impieghi dei sottoprodotti agricoli e agroindustriali. 1.

Centro Nazionale delle ricerche (CNR), 2012. Progetto "Filiera dell'energia da biomassa". Available from: http:/www.agroenergia.net/ images/stories/FEB/1_report.pdf Accessed: May 2013.

Cotana F., Cavalaglio G. 2008. La valorizzazione energetica delle potature di olivo. Quaderni Ercole Olivario n.5.

Diemoz M., Vittone G., Pantezzi T. 2003. Potatura del melo: possibili evoluzioni. Terra trentina. Gennaio 2003(1):21-23

ENAMA, 2011. Studio progetto biomasse ENAMA. Available from: http://www.enama.it/it/biomasse_studio.php Accessed: May 2013

ENEA, 2010. Atlante delle Biomasse. Available from: http://www.atlantebiomasse.enea.it. Accessed: May 2013

Isitituto Nazionale di Statistica (ISTAT), 2010. Available from: http://dati-censimentoagricoltura.istat.it/ Accessed: May 2013.

Italian Biomass Association (ITABIA), 2005. Disponibilità, caratteristiche e mercato delle biomasse in Italia. Available from: http://www.itabia.it/conoscenza.php. Accessed: May 2013.

Manzone M., 2006. Meccanizzazione degli impianti di biomassa legnosa a rapido accrescimento (SRF) per la produzione di energia. Vol. 1. PhD Diss., Università di Torino, Italy.

Musacchi S., Colombo R., Mariani M. 2011. Impiantistica e vivaismo. Available from: http://www.crpv.it/doc/44806/DLFE-1402.pdf Accessed: May 2013

Renzi M., Copini P.,Taddei A. R., Rossetti A., Gallipoli L., Mazzaglia A., Balestra G. M. 2012. Bacterial canker on Kiwifruit in Italy: Anatomical changes in the wood and in the primary infection sites. Phytopathology. 102(9):827-840

Vita in Campagna, 2012. I lavori di gennaio-febbraio. Supplemento n.1 al n.1 di Vita in Campagna, gennaio 2012, anno 30. 